\title{
Seroprevalence of Human herpesvirus 8 (HHV-8) and incidence of Kaposi's sarcoma in Iran
}

\author{
Somayeh Jalilvand ${ }^{1}$, Zabihollah Shoja', Talat Mokhtari-Azad ${ }^{1}$, Rakhshandeh Nategh ${ }^{1}$ and Ahmad Gharehbaghian ${ }^{2 *}$
}

\begin{abstract}
Seroepidemiological surveys show that the prevalence of human herpesvirus 8 (HHV-8) infection mostly varies in various geographical areas and reflects the local incidence of classic and endemic KS, being widespread in subSaharan Africa and Mediterranean countries and uncommon in the USA and Northern Europe. In the Middle East only few populations, such as Ashkenazi and Sephardic groups in Israel, have been adequately evaluated for HHV-8 seroprevalence. Among Iranian population a striking higher seroprevalence of HHV8 has been reported among haemodialysis (16.9\%), renal transplant recipients (25\%) and HIV (45.7\%) patients compared to blood donors (2\%). Kaposi's sarcoma (KS) is the rarest cancer in Iran, with an annual age-standardized incidence varying from 0.10 to 0.17 per 100,000 in males and from 0.06 to 0.08 per 100,000 in females. KS, however, is one of the most important malignancies in Iranian renal transplanted patients affecting up to $2.4 \%$ of organ recipients. The epidemiology of HHV8 and KS in Iran needs further evaluation. While the high prevalence of HHV-8 antibodies in HIV positive and haemodialysis individuals may be attributed to high-risk sexual behavior and polytransfusions, respectively, unknown determinants may be responsible for high seroprevalence of HHV8 and high incidence of KS in solid organ recipients. A global survey on HHV8 seroprevalence in Iran is mandatory to define co-factors associated with HHV8 infection and KS risk in the general Iranian population and in specific patient groups.
\end{abstract}

\section{Introduction}

Kaposi's sarcoma (KS) is a mesenchymal tumor involving blood and lymphatic vessels that was first described in Eastern Europe in the late 19th century [1] and classically considered an indolent disease of elderly men. Now days, Kaposi's sarcoma has been classified in four different clinical and epidemiological forms [2]: 1) Classic KS, mainly occurring in elderly men of Mediterranean or Eastern European origin [3-6]; 2) African-endemic KS [6-9]; 3) Iatrogenic KS, developing in solid organ transplantation recipients $[6,10-12]$ and 4) Epidemic or AIDS-associated KS [6,13-15]

In 1994 Chang et al. identified fragments of the Kaposi's sarcoma-associated herpesvirus (KSHV) genome in epidemic KS tissues, subsequently called human herpesvirus type $8(\mathrm{HHV}-8)[16]$. HHV-8 is considered to be the etiological agent of all forms of Kaposi's sarcoma [2], and has been consistently associated with two types of lymphoproliferative disease, namely body cavity-based

\footnotetext{
* Correspondence: gharehbaghian@ibto.ir

${ }^{2}$ Research Center of Iranian Blood Transfusion Organization, Tehran, Iran Full list of author information is available at the end of the article
}

lymphoma [17] as well as multicentric Castelman's disease $[16,18]$.

Seroepidemiological surveys have shown that HHV-8 infection is not ubiquitous [19]. The virus is less prevalent in northern Europe, North America, and most of Asia, and is more frequent in the Mediterranean area and parts of South America, and highly prevalent in sub-Saharan Africa [20-23]. Several studies have been performed in some Middle Eastern countries. In Israel seropositivity of HHV-8 has been ranging from $8.4 \%$ to $22 \%$ in healthy individuals [24,25]. In Saudi Arabia seroprevalence of HHV-8 was reported at $1.7 \%$ and $18 \%$ in healthy subjects and renal transplant recipients, respectively [26].

Few studies have been performed on the HHV-8 distribution and incidence of Kaposi's sarcoma in Iran. This study aimed to recapitulate available data on the seroepidemiology of HHV-8 and incidence of KS in the Iranian population. A systematic review of the published articles from January 1980 to December 2010 was conducted to assess the seroprevalence of HHV-8 and the incidence of KS in Iran. Data were identified by searches of Medline, Current Contents, PubMed, and references
C Biomed Central

() 2011 Jalilvand et al; licensee BioMed Central Ltd. This is an Open Access article distributed under the terms of the Creative Commons Attribution License (http://creativecommons.org/licenses/by/2.0), which permits unrestricted use, distribution, and reproduction in any medium, provided the original work is properly cited. 
from relevant articles, with the search terms "Kaposi's sarcoma" or "HHV-8", and "Iran".

\section{Epidemiology of classic Kaposi's sarcoma in Iran}

Data from the National Cancer Registry of Iran have reported that $\mathrm{KS}$ is the rarest cancer among Iranians [27]. Only 50, 44, and $61 \mathrm{KS}$ cases were reported in the National Cancer Registry in 2004 [27,28], 2005 [27] and $2006[27,28]$ respectively, and 101 new cases have been registered in Tehran Population Based Cancer Registry from 1998-2002 [27,29]. The annual age-standardized incidence rate was reported to be from 0.10 to 0.17 per 100,000 in males and from 0.06 to 0.08 per 100,000 in females [27]. Peak incidence has been reported at ages of 50-79 years. The male/female ratio in different reports varies from 3.2:1 to $1.8: 1$ and the elderly might be a common associated factor for KS [27]. There were no published reports about AIDS-KS in Iran.

Worldwide KS accounts for only $0.02 \%$ to $0.07 \%$ of all malignancies in the general population [30]. The regions with the highest incidence are Africa, where KS represents $3 \%$ to $9 \%$ of all cancer cases [31], Mediterranean and Eastern European areas, with specific geographic foci in Italy, Greece, and Israel $[4,5]$.

Epidemiology of post-transplant Kaposi's sarcoma in Iran The incidence of KS in kidney recipients has increased following an enormous increase in the number of kidney transplantations during the recent decades, particularly of those of Mediterranean descent [32]. Post-transplantation KS develops in $23 \%$ to $28 \%$ of HHV8 seropositive patients and in only $0.7 \%$ of seronegative patients [32-34].

The rate of chronic kidney disease and renal transplantations has increased during the last two decades in
Iran [34-36]. About 1.14-6\% ( $m e a n=2.8 \%)$ of Iranian renal transplant recipients develop cancer lesions, mostly skin cancers (Table 1) [37-43]. These findings are consistent with other report in Middle Eastern countries. The prevalence of all malignancies in renal transplant recipients was $1.9 \%$ in Pakistan [44], 4\% in Turkey [45], 6.8\% in Saudi Arabia [46], 4.8\% in Kuwait [47], $5.9 \%$ in Iraq [48], and $1.7 \%$ in Jordan [49].

$\mathrm{KS}$ is one of the most common cancers after renal transplantation in Iran [36] representing 28.5-70\% (mean $=42.2 \%)$ of all post-transplant malignancies (Table 1) [37-43]. Other reports from the Middle Eastern region showed that KS was the most common posttransplantation malignancy with frequencies of 25\% [45] and $68 \%$ in Turkey [50], 44\% in Pakistan [51], and 50\% in Iraq [48].

In Iran, incidence of KS among renal transplants varied from $0.45 \%$ to $2.4 \%$ in different studies (Table 1 ) [37,38,40-43,52-55]. In other countries of this region, the figures were $0.55 \%$ in Jordan [49], 3.2\% in Turkey [56] and 4.9\% in Saudi Arabia [46]. The incidence of KS was $0.7 \%$ [56], 1.7\% [57] and 3.9\% [58] among renal transplant recipients in Taiwan, Greece and South Africa, respectively. Therefore, the incidence of KS following kidney transplantation varies significantly in different geographic areas [59], and this is supporting the theory of ethnic or environmental factors in its pathogenesis. Globally, KS is most often seen in transplant recipients of Mediterranean, Jewish, Arabic, Caribbean, or African descent and the reported incidence ranges from $0.5 \%$ in most Western countries (including the United States) up to 5.3\% in Saudi Arabia [32].

The KS incidence among Iranian transplants recipients had a peak during the first 2 years post transplantation. The time interval between transplantation and onset of

Table 1 List of published data on the incidence of Kaposi's sarcoma in renal transplanted patients in Iran

\begin{tabular}{|c|c|c|c|c|c|c|c|c|}
\hline City & $\begin{array}{c}\text { Renal } \\
\text { Transplants }\end{array}$ & $\begin{array}{c}\text { Male/ } \\
\text { Female (N) }\end{array}$ & $\begin{array}{l}\text { Post-transplant } \\
\text { Malignancies (\%) }\end{array}$ & $\begin{array}{l}\text { KS } \\
\text { cases } \\
(\%)\end{array}$ & $\begin{array}{l}\text { Male/ } \\
\text { Female } \\
\text { (N) }\end{array}$ & $\begin{array}{l}\text { Cutaneous/ } \\
\text { visceral (N) }\end{array}$ & Study period & References \\
\hline Tehran & 681 & $438 / 243$ & - & $5(0.73)$ & $3 / 2$ & - & $2000-2002$ & [52] \\
\hline Tehran & 100 & $53 / 47$ & $6(6)$ & $2(2.0)$ & $2 / 0$ & - & 2000-2002 & [39] \\
\hline Tehran & 2211 & - & - & $10(0.45)$ & $8 / 2$ & $8 / 2$ & 1984-2007 & [53] \\
\hline Tehran & 1750 & - & $28(1.6)$ & $13(0.74)$ & - & - & 1984-1999 & [42] \\
\hline Tehran & 2050 & - & - & $18(0.87)$ & $13 / 5$ & $18 / 1$ & 1984-1999 & [54] \\
\hline Ahwaz & 580 & $330 / 250$ & $20(3.4)$ & $14(2.4)$ & $11 / 3$ & $11 / 3$ & - & [40] \\
\hline Babol & 380 & - & $12(3.15)$ & $5(1.3)$ & - & - & 1999-2005 & [41] \\
\hline Shiraz & 892 & $537 / 355$ & $21(2.3)$ & $6(0.68)$ & $5 / 1$ & $4 / 2$ & $1988-2001$ & [38] \\
\hline $\begin{array}{c}\text { Tehran, Urmia, Babol, Sari, } \\
\text { Tabriz, Hormozgan, } \\
\text { Kerman }\end{array}$ & 7,939 & $5018 / 2921$ & $162(2.04)$ & $55(0.69)$ & $33 / 22$ & $48 / 7$ & 1984-2007 & {$[37]$} \\
\hline $\begin{array}{l}\text { Tehran, Urmia, Babol, Sari, } \\
\text { Tabriz, Hormozgan, } \\
\text { Kerman, Isfahan, Ahwaz }\end{array}$ & 11,255 & $7109 / 4146$ & $128(1.14)$ & $77(0.68)$ & $48 / 29$ & - & $1984-2008$ & [43] \\
\hline
\end{tabular}


KS was relatively early compared to other skin tumors. This observation is in agreement with other studies from the Middle East region reporting appearance of KS lesions in 6.5 to 27 months following kidney transplantation [26].

The mean-age of Iranian renal transplants developing KS is below 50 years, which is lower than that of patients with classic Kaposi's sarcoma (50-79 years). This finding is consistent with data reported by other studies on renal transplant patients from different regions of the world $[30,32,45,60,61]$.

About $90 \%$ percent of transplant recipients affected by KS present cutaneous or mucosal lesions or both types. Visceral involvement occurred in $25 \%$ to $30 \%$ of kidney transplant patients [62]. Visceral lesions affected 10\% of patients and predominantly involved the lymph nodes, gastrointestinal tract, and lungs [63]. In agreement with these worldwide studies, $80 \%$ of Iranian transplant recipients with KS developed cutaneous lesions. Visceral involvement was observed in $20 \%$ of patients (Table 1 ) $[37,38,40,53,54]$.

Most cases of post-transplantation KS develop as a result of viral reactivation, since more than 80 percent of transplant recipients with KS are seropositive for HHV-8 before transplantation [34,64]. Renal recipient patients who were seropositive for HHV-8 before transplantation, have a risk to develop KS of $23 \%$ to $28 \%$ that is significantly higher compared to risk of $0.7 \%$ in patients who are seronegative before receiving a kidney transplant $[32-34,65]$.

\section{Seroepidemiology of HHV-8 in Iran}

Few serological survey on HHV-8 infection have been performed in Iran $[55,66]$. One study by Gharehbaghian et al. analyzed three groups of patients including haemodialysis patients, recruited in 2004 at the Immam-Khomeini hospital; HIV positive subjects, enrolled at the Immam-Khomeini hospital from July 2003 to June 2004; and blood donors, enrolled consecutively in a single day (June $28^{\text {th }}, 2004$ ) at the Research Center of Iranian Blood Transfusion Organization. The 256 blood donors, enrolled without any obligations, represented the $25.6 \%$ of blood samples screened on that day. All sera were tested for the presence of antibodies against HHV-8 lytic antigens by HHV-8 IgG EIA and by HHV-8 IgG IFA commercial kits (Biotrin, Ireland) as for manufacturer's instructions and each sample defined as "positive" if tested positive to both assays. The sensitivity of EIA and IFA tests was $90.4 \%$ and $100 \%$, respectively, as reported in the manufacturer's catalogue. The specificity of EIA and IFA was $93 \%$ and $94 \%$, respectively.

Among the 256 healthy Iranian blood donors $(242$ males and 14 females with mean age of 38 years, range $18-60$ years $)$ only $5(2 \%$, CI $95 \%=0.003-0.03)$, including 4 males and one female, were positive for HHV-8 antibodies. Conversely, among the 118 haemodialysis patients (63 males and 53 females with mean age of 50 years), 20 (16.9\%, CI 95\% $=0.1-0.23)$ tested positive, including 8 males and 12 females. In the HIV positive group (33 males and 2 females, the range of age 20-40 years) 16 out of the 35 patients $(45.7 \%$, CI $95 \%=0.29$ 0.62), all males, were positive for HHV-8 [55]. Also, frequency of HHV-8 positivity was not statistically significant different among haemodialysis patients stratified by number of transfusions $(P=0.36)$ [55]. Crude odds ratios and $95 \%$ confidence intervals were used to compare HHV-8 seroprevalence in different groups (Table 2). Overall, there was a statistically significant higher risk of HHV-8 seropositivity in haemodialysis $(\mathrm{OR}=$ 10.24, 95\% CI: $3.5-32.1)$ and HIV (OR $=42.27$, 95\%CI: 12.7 - 150) patients compared to blood donors, although several variables between the three enrolled groups cannot be excluded.

Low prevalence of HHV-8 in blood donors may indicate that virus is not widespread in this population; however, this study is not sufficient to determine the extrapolation of the true prevalence of HHV-8 in Iranian healthy population. Blood donors in above mentioned study were only from Tehran and it may be representative of the prevalence of HHV-8 in Tehran rather than Iran. The distribution of this virus probably is not ubiquitous in all over the Iran, so it is recommended to perform surveillance studies on different populations living in different areas of Iran in order to determine the global seroprevalence of HHV-8. Also blood donors commonly have not considered as persons

Table 2 Seroprevalence of HHV-8 among blood donors, haemodialysis, HIV-positive and renal transplants Iranian patients

\begin{tabular}{|c|c|c|c|c|}
\hline Study Population (N) & Male/Female (N) & HHV-8 positive cases (\%) & HHV8 detection Methods & References \\
\hline Blood donors (256) & $242 / 14$ & $5 / 256(2 \%)$ & Lytic [IFA-EIA]* & {$[55]$} \\
\hline Haemodialysis patients (118) & $63 / 55$ & 20/118 (16.9\%) & Lytic $\left[\right.$ IFA-EIA] ${ }^{*}$ & {$[55]$} \\
\hline Renal transplants (100) & $60 / 40$ & $25 / 100(25.0 \%)$ & LANA $[I F A]^{* *}$ & {$[66]$} \\
\hline HIV positive patients (35) & $33 / 2$ & $16 / 35(45.7 \%)$ & Lytic [IFA-EIA]* & {$[55]$} \\
\hline
\end{tabular}

* Positivity was based on positive test of both EIA and IFA assays;

** Positivity was based on positivity to a single LANA IFA assay; 
with high risk behaviors. It is better that future study populations be general population rather than blood donors to estimate more relevant prevalence of HHV-8 infection.

In another study by Ahmadpoor et al., 100 serum from Iranian renal transplant recipients (60 male, 40 female) were analyzed for antibodies against the latent nuclear antigen of HHV-8 [66] and 25\% tested seropositive for HHV-8 (Table 2). The mean age was 41.1 years (range, 17-74 years) and there was a statistically significant difference in HHV-8 seropositivity among recipients older than 55 years $(P=0.02)$. In particular, 8 out of $17(47 \%)$ patients were seropositive in the group older than 55 years, versus 17 out of $83(20 \%)$ patients in the group younger than 55 years. There were no significant differences in HHV-8 seropositivity regarding sex. Seropositive and seronegative patients were followed for 16 months and only one HHV-8 seropositive patient $(1 / 25)$ developed Kaposi's sarcoma [66]. The risk of HHV8 infection in transplanted patients is significantly higher $(\mathrm{OR}=16.73,95 \% \mathrm{CI}: 5.8-51.8)$ compared to blood donors, although different HHV8 detection methods were used (Table 2). These findings are consistent with other studies in our region reporting $18 \%$ and $28 \%$ HHV8 seroprevalence among renal transplant recipients in Saudi Arabia [26,67].

Different rates of HHV-8 infection have been reported in various populations in the world. The prevalence of HHV8 in healthy individuals was found to be $1.3 \%-4.4 \%$ in Southeast Asia and the Caribbean regions and $>40 \%$ in Africa [68-70]. In India a prevalence of $3.7 \%$ and $2.3 \%$ has been reported in healthy individuals and HIV positive patients, respectively [68]. In one study from Saudi Arabia the seroprevalence of HHV-8 in healthy Saudi national's people was reported to be $1.7 \%$ [26]. In Europe, the prevalence of HHV-8 was found to be lowest in Spain or Greece (6\%-8\%) and highest in Italy (20.4\%) [71-75]. Approximately $50 \%$ of the adult population of Brazilian Amerindians was reported to have antibodies to HHV-8 [76], compared with only $11 \%$ of HIVnegative injection drug users in Argentina [77].

\section{Conclusions}

In conclusion, in Iran a high prevalence of HHV8 infection has been observed in several risk groups such as haemodialysis, renal transplant and HIV-positive patients. KS incidence among renal transplant patients is as high as that observed in transplanted patients from endemic regions for KS. A future study including a large population from different regions of Iran is needed in order to define co-factors associated with HHV8 infection and KS risk specific patient groups in Iran.

\section{Acknowledgements}

SJ is supported by a grant from the Iranian Ministry of Health (2010-2011).

\section{Author details}

'School of Public Health, Tehran University of Medical Sciences, Tehran, Iran.

${ }^{2}$ Research Center of Iranian Blood Transfusion Organization, Tehran, Iran.

\section{Authors' contributions}

SJ conceived the study and performed a critical review of original data on HHV8 and KS prevalence in Iran in 1980-2010 period. ZS, TM-A and RN contributed to KS prevalence analysis in Iran. AG participated in the study design and coordination. All authors read and approved the final manuscript.

\section{Competing interests}

The authors declare that they have no competing interests.

Received: 31 January 2011 Accepted: 28 April 2011 Published: 28 April 2011

\section{References}

1. Kaposi M: Idiopathisches multiples pigmentsarkom her haut. Arch Dermatol Shypilol 1872, 4:265-273.

2. Schwartz RA, Micali G, Nasca MR, Scuderi L: Kaposi sarcoma: a continuing conundrum. J Am Acad Dermatol 2008, 59:179-206.

3. Iscovich J, Boffetta P, Franceschi S, Azizi E, Sarid R: Classic kaposi sarcoma: epidemiology and risk factors. Cancer 2000, 88:500-517.

4. Guttman-Yassky E, Bar-Chana M, Yukelson A, Linn S, Friedman-Birnbaum R, Bergman R, Sarid R, Silbermann M: Epidemiology of classic Kaposi's sarcoma in the Israeli Jewish population between 1960 and 1998. Br J Cancer 2003, 89:1657-1660.

5. Dal Maso L, Polesel J, Ascoli V, Zambon P, Budroni M, Ferretti S, Tumino R, Tagliabue G, Patriarca S, Federico M, Vercelli M, Giacomin A, Vicario G, Bellu F, Falcini F, Crocetti E, De LV, Vitarelli S, Piffer S, Stracci F, Serraino D, Rezza G, Franceschi S: Classic Kaposi's sarcoma in Italy, 1985-1998. Br J Cancer 2005, 92:188-193.

6. Buonaguro FM, Tomesello ML, Buonaguro L, Satriano RA, Ruocco E, Castello G, Ruocco V: Kaposi's sarcoma: aetiopathogenesis, histology and clinical features. J Eur Acad Dermatol Venereol 2003, 17:138-154.

7. Serwadda D, Carswell W, Ayuko WO, Wamukota W, Madda P, Downing RG: Further experience with Kaposi's sarcoma in Uganda. Br J Cancer 1986, 53:497-500.

8. Oettle AG: Geographical and racial differences in the frequency of Kaposi's sarcoma as evidence of environmental or genetic causes. Acta Unio Int Contra Cancrum 1962, 18:330-363.

9. Templeton AC: Kaposi's sarcoma. Pathol Annu 1981, 16:315-336.

10. Stribling J, Weitzner S, Smith GV: Kaposi's sarcoma in renal allograft recipients. Cancer 1978, 42:442-446.

11. Penn I: Kaposi's sarcoma in immunosuppressed patients. J Clin Lab Immunol 1983, 12:1-10.

12. Tessari G, Naldi L, Boschiero L, Cordiano C, Piaserico S, Fortina AB, Cerimele D, La PI, Capuano M, Gotti E, Ruggenenti P, Sassi F, Remuzzi G, Girolomoni G: Incidence and clinical predictors of Kaposi's sarcoma among 1721 Italian solid organ transplant recipients: a multicenter study. Eur J Dermatol 2006, 16:553-557.

13. Biggar RJ, Horm J, Goedert JJ, Melbye M: Cancer in a group at risk of acquired immunodeficiency syndrome (AIDS) through 1984. Am J Epidemiol 1987, 126:578-586.

14. Dal Maso L, Polesel J, Serraino D, Lise M, Piselli P, Falcini F, Russo A, Intrieri T, Vercelli M, Zambon P, Tagliabue G, Zanetti R, Federico M, Limina RM, Mangone L, De LV, Stracci F, Ferretti S, Piffer S, Budroni M, Donato A, Giacomin A, Bellu F, Fusco M, Madeddu A, Vitarelli S, Tessandori R, Tumino R, Suligoi B, Franceschi S: Pattern of cancer risk in persons with AIDS in Italy in the HAART era. Br J Cancer 2009, 100(5):840-7, 10.

15. Beral V, Peterman TA, Berkelman RL, Jaffe HW: Kaposi's sarcoma among persons with AIDS: a sexually transmitted infection? Lancet 1990, 335:123-128

16. Chang Y, Cesarman E, Pessin MS, Lee F, Culpepper J, Knowles DM, Moore PS: Identification of herpesvirus-like DNA sequences in AIDSassociated Kaposi's sarcoma. Science 1994, 266:1865-1869. 
17. Cesarman E, Chang Y, Moore PS, Said JW, Knowles DM: Kaposi's sarcomaassociated herpesvirus-like DNA sequences in AIDS-related body-cavitybased lymphomas. N Engl J Med 1995, 332:1186-1191.

18. Soulier J, Grollet L, Oksenhendler E, Cacoub P, Cazals-Hatem D, Babinet P, d'Agay MF, Clauvel JP, Raphael M, Degos L: Kaposi's sarcoma-associated herpesvirus-like DNA sequences in multicentric Castleman's disease. Blood 1995, 86:1276-1280.

19. Rezza G, Andreoni M, Dorrucci M, Pezzotti P, Monini P, Zerboni R, Salassa B, Colangeli V, Sarmati L, Nicastri E, Barbanera M, Pristera R, Aiuti F, Ortona L, Ensoli B: Human herpesvirus 8 seropositivity and risk of Kaposi's sarcoma and other acquired immunodeficiency syndrome-related diseases. J Nat/ Cancer Inst 1999, 91:1468-1474.

20. Schulz TF: Epidemiology of Kaposi's sarcoma-associated herpesvirus/ human herpesvirus 8. Adv Cancer Res 1999, 76:121-160.

21. Chatlynne LG, Lapps W, Handy M, Huang YQ, Masood R, Hamilton AS, Said JW, Koeffler HP, Kaplan MH, Friedman-Kien A, Gill PS, Whitman JE, Ablashi DV: Detection and titration of human herpesvirus-8-specific antibodies in sera from blood donors, acquired immunodeficiency syndrome patients, and Kaposi's sarcoma patients using a whole virus enzyme-linked immunosorbent assay. Blood 1998, 92:53-58.

22. Gao SJ, Kingsley L, Li M, Zheng W, Parravicini C, Ziegler J, Newton R, Rinaldo CR, Saah A, Phair J, Detels R, Chang Y, Moore PS: KSHV antibodies among Americans, Italians and Ugandans with and without Kaposi's sarcoma. Nat Med 1996, 2:925-928.

23. Simpson GR, Schulz TF, Whitby D, Cook PM, Boshoff C, Rainbow L, Howard MR, Gao SJ, Bohenzky RA, Simmonds P, Lee C, de RA, Hatzakis A, Tedder RS, Weller IV, Weiss RA, Moore PS: Prevalence of Kaposi's sarcoma associated herpesvirus infection measured by antibodies to recombinant capsid protein and latent immunofluorescence antigen. Lancet 1996, 348:1133-1138.

24. Iscovich J, Fischbein A, Fisher-Fischbein J, Freedman LS, Eng SM, Boffetta $P$, Vudovich A, Glasman C, Goldschmidt R, Livingston M, Heger-Maslansky B, Brennan P, Moore PS: Seroprevalence of Kaposi's sarcoma-associated herpesvirus in healthy adults in Israel. Anticancer Res 2000, 20:2119-2122.

25. Davidovici B, Karakis I, Bourboulia D, Ariad S, Zong J, Benharroch D, Dupin N, Weiss R, Hayward G, Sarov B, Boshoff C: Seroepidemiology and molecular epidemiology of Kaposi's sarcoma-associated herpesvirus among Jewish population groups in Israel. J Natl Cancer Inst 2001, 93:194-202.

26. Alzahrani AJ, El-Harith e, Milzer J, Obeid OE, Stuhrmann M, Al-Dayel A, Mohamed EA, Al-Egail S, Daoud M, Chowdhury A, Guella A, Aloraifi I, Schulz TF: Increased seroprevalence of human herpes virus-8 in renal transplant recipients in Saudi Arabia. Nephrol Dial Transplant 2005, 20:2532-2536.

27. Mousavi SM, Mohagheghi MA, Jerrahi AM: Epidemiology of Kaposi's sarcoma in Iran: 1984-2006. Asian Pac J Cancer Prev 2007, 8:557-560.

28. Mousavi SM, Ramazani R, Davanlou M: National Cancer Registry Report 2004-2005. Ministry of Health, Deputy to Health Directory, CDC_ Cancer Office; 2006

29. Mohagheghi MA, Mousavi A, Nahvijou A: Tehran Cancer Registry Report. (1998-2002) 2007.

30. Moray G, Basaran O, Yagmurdur MC, Emiroglu R, Bilgin N, Haberal M: Immunosuppressive therapy and Kaposi's sarcoma after kidney transplantation. Transplant Proc 2004, 36:168-170.

31. Penn I: The changing pattern of posttransplant malignancies. Transplant Proc 1991, 23:1101-1103.

32. Euvrard S, Kanitakis J, Claudy A: Skin cancers after organ transplantation. N Engl J Med 2003, 348:1681-1691.

33. Frances C, Mouquet C, Marcelin AG, Barete S, Agher R, Charron D, Benalia H, Dupin N, Piette JC, Bitker MO, Calvez V: Outcome of kidney transplant recipients with previous human herpesvirus-8 infection. Transplantation 2000, 69:1776-1779.

34. Cattani P, Capuano M, Graffeo R, Ricci R, Cerimele F, Cerimele D, Nanni G, Fadda G: Kaposi's sarcoma associated with previous human herpesvirus 8 infection in kidney transplant recipients. J Clin Microbiol 2001, 39:506-508.

35. Nafar M, Einollahi B, Sharifian M, Firoozan A, Aghighi M: Renal transplantation in Iran. Transplant Proc 2001, 33:2649.

36. Einollahi B, Taheri S: Renal transplantation practice in Iran and the Middle East: report from Iran and a review of the literature. Ann Transplant 2008, 13:5-14
37. Einollahi $B$, Lessan-Pezeshki M, Nourbala MH, Simforoosh N, Pourfarziani V, Nemati E, Nafar M, Basiri A, Pour-Reza-Gholi F, Firoozan A, Ghadiani MH, Makhdoomi K, Ghafari A, Ahmadpour P, Oliaei F, Ardalan MR, Makhlogh A Samimagham HR, Azmandian J: Kaposi's sarcoma following living donor kidney transplantation: review of 7,939 recipients. Int Urol Nephrol 2009, 41:679-685.

38. Bahador A, Hosseini SA, Salahi H, Jalali GA, Behzadi S, Davari HR, Javid R, Janghorban P: Malignancies in kidney transplant recipients: 13 years of experience. Transplant Proc 2003, 35:2710-2711.

39. Ghaninejad $H$, Ehsani AH, Ghiasi M, Noormohammadpour P, Najafi E, Naderi G, Ganji M, Mirnezami M, Nezami R, Kiani P: Benign and malignant skin lesions in renal transplant recipients. Indian J Dermatol 2009, 54:247-250.

40. Shahbazian H: Kaposi sarcoma in kidney transplanted patients. Urol J 2004, 1:111-114.

41. Akbarzadehpasha A, Oliaei F, Asrari MR, izadeh-Navaei R: Comparison of demographic data and immunosupression protocol in patients with and without malignancy after kidney transplantation. Saudi J Kidney Dis Transpl 2010, 21:1044-1047.

42. Einollahi B, Noorbala MM, Lessan PM, Khatami MR, Simforoosh N, Firoozan A, Nafar M: Incidence of postrenal transplantation malignancies: a report of two centers in Tehran, Iran. Transplant Proc 2001, 33:2812.

43. Einollahi B, Nemati $E$, Lessan-Pezeshki M, Simforoosh N, Nourbala MH, Rostami Z, Nafar M, Pourfarziani V, Beiraghdar F, Mahdavi-Mazdeh M, Ahmadpour P, Makhdoomi K, Ghafari A, Ardalan MR, Taebi KH, Oliaei F, Shahidi S, Makhlogh A, Azmandian J, Samimagham HR, Shabazian H: Skin cancer after renal transplantation: Results of a multicenter study in Iran. Ann Transplant 2010, 15:44-50.

44. Askari H, Hashmi A, Lal M, Ali B, Hussain M, Hussain Z, Naqvi Z, Rizvi A: Postrenal transplant malignancies in a living-related donor program: 13year experience-an update. Transplant Proc 1999, 31:3236.

45. Arican A, Karakayali H, Coskun M, Colak T, Erdal R, Haberal M: Incidence and clinical characteristics of malignancies after renal transplantation: one center's experience. Transplant Proc 2001, 33:2809-2811.

46. Shaaban AA: Incidence and types of malignant tumors in renal transplant recipients: a single center experience. Saudi J Kidney Dis Transpl 1998, 9:116-122.

47. Samhan M, Al-Mousawi M, Donia F, Fathi T, Nasim J, Nampoory MR: Malignancy in renal recipients. Transplant Proc 2005, 37:3068-3070.

48. Altaee IK, Jaleel NA, Aljubury HM, Alshamaa IA, Gazala S: Incidence and types of malignancies in renal transplant recipients in Iraq. Saudi J Kidney Dis Transp/ 2006, 17:408-414.

49. Al-Akash N, Gneimat M, Hadidi M, El LM: Malignancy in renal transplant recipients at king hussein medical center. Saudi J Kidney Dis Transp/ 1995, 6:400-402.

50. Ecder ST, Sever MS, Yildiz A, Turkmen A, Kayacan SM, Kilicaslan I, Kocak T, Eldegez U: Kaposi's sarcoma after renal transplantation in Turkey. Clin Transplant 1998, 12:472-475.

51. Lal M, Alamdar S, Ali B, Hussain M, Hashmi A, Hussain Z, Naqvi A, Rizvi A: Postrenal transplant malignancies in a living-related donor program. Transplant Proc 1998, 30:822-823.

52. Alimagham M, mini-Afshar S, Farahmand S, Pour-Kazemi A, Pour-RezaGholi F, Masood S: Frequency of infectious skin lesions in kidney transplant recipients. Urol J 2005, 2:193-196.

53. Abbaszadeh S, Taheri S: Kaposi's sarcoma after renal transplantation. Saudi J Kidney Dis Transpl 2009, 20:775-778.

54. Lessan-Pezeshki M, Einollahi B, Khatami MR, Mahdavi M: Kidney transplantation and Kaposi's sarcoma: review of 2050 recipients. Transplant Proc 2001, 33:2818.

55. Gharehbaghian A, Zaghal A, Farhudi Langerudi M, Karimi GH: Seroepidemiology of the human Herpesvirus (HHV-8) in the haemodialysis patients blood donors and HIV-positive individuals in City of Tehran. Journal of School of Public Health and Institute of Public Health Research 2006, 4:57-62.

56. Huang JY, Chiang YJ, Lai PC, Shih LY, Huang CC, Chu SH, Wu CH: Posttransplant Kaposi's sarcoma: report from a single center. Transplant Proc 2004, 36:2145-2147.

57. Zavos G, Bokos J, Papaconstantinou I, Boletis J, Gazouli M, Kakisis J, Zografidis A, Kostakis A: Clinicopathological aspects of 18 Kaposi's sarcoma among 1055 Greek renal transplant recipients. Artif Organs 2004, 28:595-599. 
58. Moosa MR: Kaposi's sarcoma in kidney transplant recipients: a 23-year experience. QJM 2005, 98:205-214.

59. Frances C: Kaposi's sarcoma after renal transplantation. Nephrol Dial Transplant 1998, 13:2768-2773.

60. Bernieh B, Nezamuddin N, Sirwal IA, Wafa A, Abbade MA, Nasser B, Al RZ: Short-tem Post Renal Trasplant Follow-up at Madinah Al Munawarah. Saudi J Kidney Dis Transpl 1999, 10:493-497.

61. Piselli $P$, Busnach $G$, Citterio F, Frigerio M, Arbustini E, Burra P, Pinna AD, Bresadola V, Ettorre GM, Baccarani U, Buda A, Lauro A, Zanus G, Cimaglia C, Spagnoletti G, Lenardon A, Agozzino M, Gambato M, Zanfi C, Miglioresi L, Di GP, Mei L, Ippolito G, Serraino D: Risk of Kaposi sarcoma after solidorgan transplantation: multicenter study in 4,767 recipients in Italy, 1970-2006. Transplant Proc 2009, 41:1227-1230.

62. Farge D: Kaposi's sarcoma in organ transplant recipients. The Collaborative Transplantation Research Group of lle de France. Eur J Med 1993, 2:339-343.

63. Penn I: Kaposi's sarcoma in transplant recipients. Transplantation 1997, 64:669-673.

64. Allen UD: Human herpesvirus type 8 infections among solid organ transplant recipients. Pediatr Transplant 2002, 6:187-192.

65. Emond JP, Marcelin AG, Dorent R, Milliancourt C, Dupin N, Frances C, Agut H, Gandjbakhch I, Calvez V: Kaposi's sarcoma associated with previous human herpesvirus 8 infection in heart transplant recipients. Clin Microbiol 2002, 40:2217-2219.

66. Ahmadpoor P, Ilkhanizadeh B, Sharifzadeh P. Makhdoomi K, Ghafari A, Nahali A, Yekta Z, Noroozinia F: Seroprevalence of human herpes virus-8 in renal transplant recipients: a single center study from Iran. Transplant Proc 2007, 39:1000-1002.

67. Qunibi W, Al-Furayh O, Almeshari K, Lin SF, Sun R, Heston L, Ross D, Rigsby M, Miller G: Serologic association of human herpesvirus eight with posttransplant Kaposi's sarcoma in Saudi Arabia. Transplantation 1998, 65:583-585.

68. Ablashi D, Chatlynne L, Cooper H, Thomas D, Yadav M, Norhanom AW, Chandana AK, Churdboonchart V, Kulpradist SA, Patnaik M, Liegmann K, Masood R, Reitz M, Cleghorn F, Manns A, Levine PH, Rabkin C, Biggar R, Jensen F, Gill P, Jack N, Edwards J, Whitman J, Boshoff C: Seroprevalence of human herpesvirus-8 (HHV-8) in countries of Southeast Asia compared to the USA, the Caribbean and Africa. Br J Cancer 1999, 81:893-897.

69. Andreoni M, El-Sawaf G, Rezza G, Ensoli B, Nicastri E, Ventura L, Ercoli L, Sarmati L, Rocchi G: High seroprevalence of antibodies to human herpesvirus-8 in Egyptian children: evidence of nonsexual transmission. J Natl Cancer Inst 1999, 91:465-469.

70. Sitas F, Newton R, Boshoff C: Increasing probability of mother-to-child transmission of HHV-8 with increasing maternal antibody titer for HHV8. N Engl J Med 1999, 340:1923.

71. de Sanjose S, Marshall V, Sola J, Palacio V, Almirall R, Goedert JJ, Bosch FX, Whitby D: Prevalence of Kaposi's sarcoma-associated herpesvirus infection in sex workers and women from the general population in Spain. Int J Cancer 2002, 98:155-158.

72. Gambus G, Bourboulia D, Esteve A, Lahoz R, Rodriguez C, Bolao F, Sirera G, Muga R, del RJ, Boshoff C, Whitby D, Casabona J: Prevalence and distribution of HHV-8 in different subpopulations, with and without HIV infection, in Spain. AIDS 2001, 15:1167-1174

73. Valdarchi C, Serraino D, Cordiali FP, Castilletti C, Trento E, Farchi F, Rezza G: Demographic indicators and risk of infection with human herpesvirus type 8 in Central Italy. Infection 2007, 35:22-25.

74. Whitby D, Smith NA, Matthews S, O'Shea S, Sabin CA, Kulasegaram R, Boshoff C, Weiss RA, de RA, Best JM: Human herpesvirus 8 : seroepidemiology among women and detection in the genital tract of seropositive women. J Infect Dis 1999, 179:234-236.

75. Zavitsanou A, Sypsa V, Petrodaskalaki M, Kalapothaki V, Whitby D, Hatzakis A: Human herpesvirus 8 (HHV-8) infection in healthy urban employees from Greece: seroprevalence and associated factors. J Med Virol 2007, 79:591-596.

76. Biggar RJ, Whitby D, Marshall V, Linhares AC, Black F: Human herpesvirus 8 in Brazilian Amerindians: a hyperendemic population with a new subtype. J Infect Dis 2000, 181:1562-1568.

77. Sosa C, Benetucci J, Hanna C, Sieczkowski L, Deluchi G, Canizal AM, Mantina H, Klaskala W, Baum M, Wood C: Human herpesvirus 8 can be transmitted through blood in drug addicts. Medicina (B Aires) 2001, 61:291-294.

doi:10.1186/1750-9378-6-5

Cite this article as: Jalilvand et al:: Seroprevalence of Human herpesvirus 8 (HHV-8) and incidence of Kaposi's sarcoma in Iran. Infectious Agents and Cancer 2011 6:5.

\section{Submit your next manuscript to BioMed Central and take full advantage of:}

- Convenient online submission

- Thorough peer review

- No space constraints or color figure charges

- Immediate publication on acceptance

- Inclusion in PubMed, CAS, Scopus and Google Scholar

- Research which is freely available for redistribution

Submit your manuscript at www.biomedcentral.com/submit
Ciomed Central 